\title{
PENGARUH PENERAPAN TA'ZIR DALAM MENINGKATKAN KEDISIPLINAN SANTRI DI PONDOK PESANTREN NURUL HUDA BANAT SIMBANG KULON BUARAN PEKALONGAN
}

\author{
Fathatur Rizqiyah \\ Institut Agama Islam Negeri Pekalongan \\ Fatkhaturrizqiyah7@gmail.com
}

\begin{abstract}
This study discusses the efforts of the Islamic boarding school in dealing with deviant behavior in students at the Nurul Huda Banat Islamic boarding school Simbang Kulon Buaran Pekalongan. This research is motivated by the problem of deviant behavior carried out by students at the Nurul Huda Banat Islamic boarding school. Deviant behavior with violations of the rules and regulations set by the pesantren. Pesantren has a very important role in building morale in students and has a very important role in overcoming deviations committed by students. This study aims to determine how the influence of ta'zir on the discipline of students, this study uses a qualitative approach and case study methods. Data was collected by using interview, observation, and documentation techniques. The research information consisted of the boarding school administrator and one of the female students of the Nurul Huda Banat Islamic boarding school. It is hoped that the existence of ta'zir can foster a disciplined attitude in students.
\end{abstract}

Keyword: Ta'zir, Violations

\begin{abstract}
Abstrak : Penelitian ini membahas upaya pondok pesantren dalam mengatasi perilaku yang menyimpang pada santri di pondok pesantren Nurul Huda Banat Simbang Kulon Buaran Pekalongan. Penelitian ini dilatarbelakangi oleh adanya permasalahan perilaku menyimpang yang dilakukan oleh santri di pondok pesantren Nurul Huda Banat. Perilaku menyimpang berkaitan dengan pelanggaran-pelanggaran peraturan tata tertib yang telah ditetapkan oleh pesantren. Pesantren memiliki peranan yang sangat penting dalam membentuk moral pada diri santri dan memiliki peran yang sangat penting dalam mengatasi penyimpangan yang dilakukan oleh santri. Penelitian ini bertujuan untuk mengetahui bagaimana pengaruh ta'zir terhadap kedisiplinan santri, penelitian ini menggunakan pendekatan kualitatif dan metode studi kasus. Pengumpulan data dilakukan dengan teknik wawancara, observasi, dan dokumentasi. Informasi penelitian terdiri dari pengurus pondok dan salah satu santri perempuan pondok pesantren Nurul Huda Banat. Diharapkan dengan adanya ta'zir mampu menumbuhkan sikap kedisiplinan dalam diri santri.
\end{abstract}

Kata Kunci: Ta'zir, Pelanggaran

Islamika : Jurnal Keislaman dan Ilmu Pendidikan

Volume 3, Nomor 2, Juli 2021; 163-170

https:// ejournal.stitpn.ac.id/index.php/islamika 


\section{PENDAHULUAN}

Menurut Ahmad Tafsir, "Istilah pesantren merupakan lembaga pendidikan Islam tertua di Indonesia yang telah berfungsi sebagai salah satu pusat dakwah dan pusat pengembangan masyarakat muslim Indonesia" (2008; 120). Pondok pesantren sebagai wadah untuk mencari ilmu dan belajar ilmu agama islam dan sebagai tempat tinggal para santri. Sedangkan pondok, kiai, , santri, masjid dan pengajian kitab-kitab klasik merupakan lima elemen dasar bagi pondok pesantren (Daulay; 2001). ${ }^{1}$

Pesantren menjadi salah satu Rahim yang meneteskan para pejuang yang selain militant, juga bertanggung jawab penuh terhadap tugas serta lingkungannya. Bertanggung jawab secara vertical atau horizontal dalam melahirkan serta membesarkan Indonesia. Hal ini karena pesantren sebagai kawah candradimuka bagi para santri sebelum benar-benar terjun ke lingkungan masyarakat. Dalam penegasan lain pesantren merupakan Lembaga multi fungsional yang tidak sekedar mengenai hal perkembangan ilmu agama islam, namun berperan penting dalam pembangunan lingkungan masyarakat sekitar. Pondok pesantren juga merupakan acuan atau titik utama Pendidikan agama islam yang berkembang dan diakui oleh masyarakat sekitar. Keberadaan pesantren di Indonesia juga terpencar diberbagai penjuru meskipun sampai ke pelosok negeri. ${ }^{2}$

Pondok pesantren merupakan Lembaga Pendidikan islam tradisional yang sudah ada sejak dahulu sebelum Indonesia merdeka. Pondok pesantren biasanya di asuh oleh seorang Kiai yang sangat disegani dan dihormati dan dita'ati. Pendidikan pesantren memiliki tujuan menciptakan dan mengembangkan kepribadian muslim dengan meninggikan moral, menghargai nilai-nilai spiritual dan kemanusiaan, menjadikan santri mampu untuk hidup secara sederhana dan bersih hati dan bermanfaat bagi masyarakat. ${ }^{3}$

1 Suyono, Herimanto dan Sri Wahyuni, "Peranan Pondok Pesantren dalam Mengatasi Kenakalan Remaja, (Studi kasus di pondok pesantren Al-Muayyad Surakarta)", Jurnal Penelitian dan Pengabdian, Vol. 6, No. 2010. hlm. 4.

2 Wiwin Fitriyah, Abd Hamid Wahid, dan Chucnul Muali, "Eksistensi Pesantren dalam Pembentukan Kepribadian Santri”, Jurnal Studi Keislaman dan Ilmu Pendidikan, Vol. 6, No. 2, 2018, hlm. 156-158.

3 Lailatus Sa'adah, "Tradisi Ta'ziran di Pondok Pesantren Roudlatul Mut'allimin Desa Datinawong, Kecamatan Babat, Kabupaten Lamongan", Jurnal Penelitian Medika Eksakta, Vol. 5, No. 2, 2016, hlm. 1 . 
Menurut Alex Sobur, disiplin berasal dari kata asing yaitu discipline (Inggris), disclipine (Belanda), Disclipina (Latin), yang berarti belajar. Dalam arti yang lebih luas disiplin berarti setiap macam yang memberika pengaruh yang diberikan kepada anak untuk menolong anak mempelajari cara-cara menghadapi tuntunan yang datang dari lingkungan dan juga cara-cara menyelesaikan tuntunan-tuntunan yang mungkin diajukan terhadap lingkungannya. Peningkatan kedisiplinan santri dapat di ukur melalui pengamatan terhadap santri yang menonjolkan perubahan sikap dan tingkah laku yang lebih baik. Kedisiplinan santri merupakan perbuatan dan tingkah laku yang dimiliki oleh santri yang menunjukkan hal positif dan di peroleh dari kesadaran yang tinggi melalui menaati peraturan dan tata tertib yang ditetapkan oleh pesantren adalah bentuk kewajiban bagi setiap individu santri. ${ }^{4}$

Pendidikan merupakan jalan untuk mendisiplinkan, hal ini merupakan tugas setiap Lembaga Pendidikan. Tak terkecuali untuk pesantren yang dipimpin oleh Kiai. Kiai sebagai pemimpin di pesantren memiliki strategi tersendiri dalam mendisiplinkan santrinya sesuai dengan kemampuan Kiai tersebut. Pembiasaan sikap disiplin yang di haruskan oleh Kiai akan melatih santri mengontrol sehingga mampu untuk mengembangkan sikap pengendalian dalam dirinya, dan pengarahan diri, santri mampu menentukan sikap secara mandiri tanpa adanya pengaruh dari luar yang mampu memberikan efek yang tidak berarti. ${ }^{5}$

${ }^{4}$ Mukhimatul Farikhah, "Penerapan Metode Ta'zir dalam Meningkatkan Kedisiplinan Santri di Pondok Pesantren Roudlatul 'Ilmi Kranggan Kecamatan Pekuncen Kabupaten Banyumas”. Skripsi (Purwokerto: IAIN Purwokerto 2019) hlm, 7-9.

${ }^{5}$ Isna Iffatul Hamidiyah, "Pengaruh Kepemimpinan Kiai dan Penerapan (Ta'zir) Terhadap Kedisiplinan Santri Pondok Pesantren Al-Barokah Mangunsuman Siman Ponorogo". Skripsi (Ponorogo: IAIN Ponorogo 2020), hlm. 2-3. 
Di pondok pesantren terdapat banyak tradisi-tradisi yang masih dijalankan hingga sekarang, yaitu contohnya sholat berjamaah, berzani setiap malam jum'at, ro'an (bersih-bersih lingkungan pondok) biasanya dilakukan setiap hari jum'at secara serentak, Khotmil qur'an, pengajian al-qur'an, pengajian kitab kuning, belajar Bersama, musyawarah shalat malam, muludan, rajaban dan ta'zir. Dalam hal ini penulis sangat tertarik dengan yang Namanya Ta'zir. Ta'zir memang sudah sangat erat dengan kehidupan yang ada di pondok pesantren dari dulu hingga sekarang. Dengan adanya ta'zir memberikan sebuah fungsi kewibawaan tersendiri terhadap peraturan dan tata tertib yang ada di pondok pesantren.

Hukuman dipondok pesantren biasa dikenal dengan istilah Ta'z̧ir. Ta'zir merupakan istilah yang sudah tidak asing lagi di dunia pesantren, ta'żir adalah suatu sanksi yang diberikan kepada santri yang telah melakukan pelanggaran peraturan pondok pesantren yang memiliki tujuan untuk memberikan efek jera terhadap santri yang melakukan pelanggaran dan membuatnya agar tidak mengulangi kesalahan yang smaa. Ta'zir sebagai sebuah istilah yang sudah sangat familiar di lingkungan pondok pesantren yang berkaitan erat dengan kedisiplinan. Mulanya, disiplin dibentuk bersifat eksternal yaitu dari lingkungan orang tua maupun lingkungan luar namun kemudian menjai suatu yang internal Bersatu menjadi sebuah kepribadian anak dan akhirnya disebut sebagai kedisiplinan diri. Seperti yang ada di dunia pondok pesantren. Pelanggaran yang dilakukan santri akan merasa aman Ketika tidak diberikan hukuman atau ta'zir dari akibat adanya perbuatan yang salah. Tujuan utama dari adanya ta'zir untuk memberikan efek jera agar tidak mengulangi kesalahan yang sama. Ta'zir diharapkan mampu untuk meningkatkan rasa kedisiplinan dalam diri santri. Kedisiplinan dibentuk bukan semata-mata untuk memberikan rasa takut atau trauma terhadap santri, justru hal ini dilakukan untuk mendidik para santri agar sanggup mengontrol dirinya dalam berperilaku serta bisa memanfaatkan waktu dengan sebaik mungkin. ${ }^{6}$

6 Muhammad Al-Musdhaqiron, “Implementasi Ta'zir dalam Upaya Meningkatkan Kedisiplinan Santri di Pondok Roudlatul Rohmaniyah Sukolumajang, Jurnal Dakwah dan komunikasi Islam, Vol. 3, No. 2, 2017, hlm. 30. 
Beberapa penelitian yang sudah dilakukan mengenai pelaksanaan ta'zir antara lain: Muhammad Al Musdhaqiron 'Implementasi Ta'zir dalam Upaya Meningkatkan Kedisiplinan Santri di Pondok Pesantren Roudlatul Rohmaniyah Sukolumajang”. Jurnal Dakwah dan komunikasi Islam, Vol. 3, No. 2, 2017. Menyimpulkan bahwa bentuk implementasi ta'zir di pondok pesantren roudlatul rohmaniyah ada 2 yaitu ta'zir fisik dan non fisik. Walaupun ada ta'zir yang bersifat fisik namun hal ini tidak tetap slam lingkup kemanfaatan dalam ta'zir tersebut dan dalam memberikan hukuman pun melalui tahapan-tahapan dan memberikan efek terhadap santri agar mau mengakui atas kesalahannya. Salah satu tujuan adanya ta'zir guna membentuk kedisiplinan santri yang menjadikan santri mampu untuk melatih dan mengontrol sehingga santri dapat dengan mudah mengembangkan sikap pengendalian dalam diri sendiri.

\section{METODE PENELITIAN}

Penelitian ini merupakan penelitian kualitatif dengan menggunakan metode studi kasus. Penelitian ini dilakukan di pondok pesantren Nurul Huda Banat simbang Kulon Buaran Pekalongan. Memilih pondok pesantren Nurul Huda Banat sebagai objek penelitian karena didalamnya terdapat santri yang melakukan pelanggaranpelanggaran terhadap tata tertib peraturan yang sudah ditetapkan oleh Pesantren. Hal ini sesuai dengan tujuan penelitian yaitu mengetahui bagaimana pengaruh ta'zir terhadap kedisiplinan Santri, sedangkan subjek yang diambil dalam penelitian ini adalah pengurus pondok pesantren dan salah satu santri pondok pesantren Nurul Huda Banat yang berperilaku menyimpang atau melakukan pelanggaran. Adapun teknik pengumpulan data yang digunakan dalam penelitian ini adalah wawancara mendalam, observasi, dan studi dokumentasi.

\section{HASIL DAN PEMBAHASAN}

Strategi yang dilakukan oleh pondok pesantren Nurul Huda Banat dalam mengatasi pelanggaran-pelanggaran yang dilakukan oleh santri yaitu salah satunya dengan ta'zir, sehingga dengan adanya upaya tersebut santri dapat mengontrol 
perilakunya dan tidak mengulangi pelanggaran tersebut. Berdasarkan data yang diperoleh apabila santri melakukan pelanggaran maka akan langsung diberikan ta'zir jika pelanggaran tersebut sudah tertulis dalam buku peraturan yang sudah di buat oleh pengurus berdasarkan musyawarah dengan ustadz atau ustadzah pondok dan juga dengan pengasuh pondok pesantren. Pihak yang menangani perilaku pelanggaran santri ditangani oleh pengurus pondok pesantren. Jika pelanggaran tetap dilakukan berulang-ulang oleh santri maka penanganan santri yang melakukan pelanggaran langsung ditangani oleh Ustadz atau Ustadzah pondok. Begitu halnya pada pelanggaran dengan kategori berat, pengurus pondok akan melibatkan Ustadz atau Ustadzah dalam menangani santri dan memberi keputusan terkait hukuman yang diterima Santri. Sedangkan kategori pelanggaran yang ringan, ditangani oleh pengurus begitu pula pelanggaran yang sedang Penanganannya dilakukan dengan kerjasama antara pengurus pondok dan Ustadz atau Ustadzah pondok.

Pengurus pondok pesantren terlebih Departemen Keamanan selalu berupaya dalam menngani santri yang melakukan pelanggaran-pelanggaran. Upaya yang pertama jika santri melanggar peraturan pondok sesuai dengan yang sudah tertulis maka santri akan lansung diberikan ta'zir atau hukuman sesuai dengan kategori pelanggaran tersebut. Jika santri ketahuan melakukan pelanggaran maka akan langsung diberi ta'zir atau hukuman sesuai dengan yang sudah tertulis. Kategori ta'zir dibagi menjadi tiga, ta'zir ringan, ta'zir sedang dan ta'zir berat. Pemberian ta'zir diberikan kepada santri berdasarkan pelanggaran yang diperbuat oleh santri tersebut. Ta'zir berlaku bagi seluruh santri yang melakukan pelanggaran, bagi santri yang melakukan pelanggaran dengan kategori berat maka akan langsung diberi ta'zir oleh ustadz atau ustadzah pondok dan jika tetap melakukan pelanggaran maka akan diserahkan langsung kepada pengasuh pondok pesantren. Selain itu bagi santri yang melakukan pelanggaran berupa keluar pondok tanpa seizin pengurus atau pulang kerumah dan Kembali ke pondok melebihi batas waktu yang diberikan maka akan diberikan ta'zir berupa membersihkan kamar mandi, jemuran pondok atau membersihkan area sekitar halaman pondok. Adapun selain ta'zir yang sudah dijelaskan ada ta'zir berupa dendan, denda diberikan kepada santri yang melakukan pelanggaran tata tertib berdasarkan kategori tertentu saja. 
Berdasarkan dari hasil wawancara dengan salah satu santri yang melakukan pelanggaran, ta'zir yang diberikan menjadikan santri tersebut takut dan tidak ingin mengulangi pelanggaran tersebut, berarti dalam hal ini pengaruh yang diberikan dengan adanya ta'zir terhadap kedisiplinan santri memberika efek yang baik. Sehingga adanya ta'zir tersebut memang memberikan dampak yang signifikan terhadap kedisiplinan santri di pondok pesantren Nurul Huda Banat. Santri juga tidak merasa terbebani dengan adanya ta'zir tersebut karena hal tersebut diberikan guna memberiakn efek jera agar santri tidak melakukan pelanggaran Kembali dan bentuk tanggung jawab atas kesalahan yang sudah diperbuat. Ta'zir juga menumbuhkan rasa tidak ingin mengulangi pelanggaran dan cenderung menyesali atas apa yang sudah diperbuat, ta'zir juga bertujuan untuk menjadikan santri agar menjadi pribadi yang lebih baik lagi. Alasan santri melakukan pelanggaran salah satunya adalah mereka bosen atau cenderung ingin merasakan kebebasan di luar dari peraturan yang sudah ditetapkan dan butuh hiburan. Ta'zir juga memberikan rasa intropeksi diri terhadap kesalahan yang sudah dilakukan. ${ }^{7}$

\section{KESIMPULAN}

Ta'zir merupakan bentuk upaya pihak pondok pesantren dalam menangani santri yang melakukan pelanggaran. Sehingga dengan adanya ta'zir tersebut diharapkan santri mampu menumbuhkan sikap kedisiplinan yang tinggi untuk selalu menaati tata tertib peraturan pondok pesantren yang sudah ditetapkan. Tujuan utama dari adanya ta'zir untuk memberikan efek jera agar tidak mengulangi kesalahan yang sama. Ta'zir diharapkan mampu untuk meningkatkan rasa kedisiplinan dalam diri santri. Kedisiplinan dibentuk bukan semata-mata untuk memberikan rasa takut atau trauma terhadap santri, justru hal ini dilakukan untuk mendidik para santri agar sanggup mengontrol dirinya dalam berperilaku serta bisa memanfaatkan waktu dengan sebaik mungkin. Ta'zir dibagi menjadi tiga tahapan yaitu ta'zir ringan, ta'zir sedang, dan ta'zir berat. Ta'zir tersebut memang memberikan dampak yang signifikan terhadap kedisiplinan santri di pondok pesantren Nurul Huda Banat. Santri juga tidak merasa

7 Wawancara dengan Pengurus Pondok Pesantren Nurul Huda Banat Simbang Kulon Buaran Pekalongan, pada kamis 24 juni 2021, pukul 22.10 Wib. 
terbebani dengan adanya ta'zir tersebut karena hal tersebut diberikan guna memberiakn efek jera agar santri tidak melakukan pelanggaran Kembali dan bentuk tanggung jawab atas kesalahan yang sudah diperbuat.

\section{DAFTAR PUSTAKA}

Isna Iffatul Hamidiyah, "Pengaruh Kepemimpinan Kiai dan Penerapan (Ta'zir) Terhadap Kedisiplinan Santri Pondok Pesantren Al-Barokah Mangunsuman Siman Ponorogo". Skripsi (Ponorogo: IAIN Ponorogo 2020).

Lailatus Sa'adah, “Tradisi Ta'ziran di Pondok Pesantren Roudlatul Mut'allimin Desa Datinawong, Kecamatan Babat, Kabupaten Lamongan", Jurnal Penelitian Medika Eksakta, Vol. 5, No. 2, 2016.

Muhammad Al-Musdhaqiron, "Implementasi Ta'zir dalam Upaya Meningkatkan Kedisiplinan Santri di Pondok Roudlatul Rohmaniyah Sukolumajang, Jurnal Dakwah dan komunikasi Islam, Vol. 3, No. 2, 2017.

Mukhimatul Farikhah, "Penerapan Metode Ta'zir dalam Meningkatkan Kedisiplinan Santri di Pondok Pesantren Roudlatul 'Ilmi Kranggan Kecamatan Pekuncen Kabupaten Banyumas". Skripsi (Purwokerto: IAIN Purwokerto 2019).

Suyono, Herimanto dan Sri Wahyuni, "Peranan Pondok Pesantren dalam Mengatasi Kenakalan Remaja, (Studi kasus di pondok pesantren Al-Muayyad Surakarta)", Jurnal Penelitian dan Pengabdian, Vol. 6, No. 2010.

Wiwin Fitriyah, Abd Hamid Wahid, dan Chucnul Muali, "Eksistensi Pesantren dalam Pembentukan Kepribadian Santri", Jurnal Studi Keislaman dan Ilmu Pendidikan, Vol. 6, No. 2, 2018. 